\title{
Inequality of income, asset and debt of inland fishers in the Theni District of Tamil Nadu, India
}

\author{
KALIDOSS RADHAKRISHNAN, R. MARIMUTHU*, M. RAJAKUMAR* AND NEHA W. QURESHI \\ ICAR-Central Institute of Fisheries Education, Versova, Mumbai - 400 061, Maharashtra, India \\ "Fisheries College and Research Insitute, Tamil Nadu Fisheries University, Thoothukudi - 628 008, Tamil Nadu, India \\ e-mail: marimuthu.kombai@gmail.com
}

\begin{abstract}
In the present study, an attempt was made to measure the impact of inequality on income, asset and debt of inland fishers in the Theni District of Tamil Nadu, India. A total of 140 respondents were surveyed for this work. Gini index (GI) was applied to measure the income inequality and multiple regression was done to identify the influencing variable of asset and debt. Higher income was observed in non-fishing activities than those of the fishing and fishing related works while higher income equality was recorded in fishing. Among assets, fishing gear, craft, television and land had lesser inequality (GI 0.06 to 0.41 ) while furniture and livestock had higher inequality (GI 0.0 to 0.80 ). Average debt was found to be higher among institutional sources than that of the non-institutional ones, whereas, a minimum GI (0.59) was recorded in Vagai and maximum GI (0.76) in Kullapuram. Results of the study indicate that there is a need for curtailing credits from non-institutional sources, which burden fishers and affect their economic status. Also, the fishing sector in Tamil Nadu needs proper policy attention regarding education and well-designed market policies as well as institutions to minimise the inequality that is plaguing the sector.
\end{abstract}

Keywords: Gini coefficient, Income inequality, Inland fishers, Regression

\section{Introduction}

With the increasing population and their subsequent nutritional requirement, inland fisheries have to play a lead role, because fish production from marine sources has reached a plateau and has remained stagnant during recent past. The inland fish production has grown from 2.18 lakh $\mathrm{t}$ in 1950-51 into 57.19 lakh $\mathrm{t}$ in 2012-13 (HBFS, 2014). This huge growth was achieved from the inland capture (area) and culture fisheries (total aquaculture area of 2.388 lakh ha). Therefore, the contribution of inland fishers to fish production is indispensable and studies have been done around the world to assess their social and economic status (Baran et al., 2007; Nath, 2015; Lynch et al., 2016). However, the distribution of income was not even all over the world; it was majorly influenced by the type of fish farming practices, the area of operation and type of species cultured. High income makes higher assets along with low debt. The inequality affects the growth and economics at the national level (Forbes, 2000; Fredriksen, 2012). Income inequality had the upshot on the household debt (Iacoviello, 2008), consumption (Krueger and Perri, 2006), its dimension (Ahluwalia, 1974) and trend (Cingano, 2014). The income in asset inequality has an event on poverty reduction (Birdsall and Londono, 1997). However, only a few studies have been conducted on inequality in inland fisheries; therefore, there exists paucity in information about the present status. This study has addressed the income inequality of inland fishers of Theni District, Tamil Nadu together with the determinants of the assets and debt.

\section{Materials and methods}

The present investigation was conducted in Theni District, Tamil Nadu. The primary data was collected from 20 respondents each from 7 cooperative societies viz., Andipatti, Bodi, Cumbum, Kullapuram, Periyakulam, Theni and Vaigai) by adopting two-stage random sampling between August 2014 and May 2015. Secondary information was sourced from the Department of Fisheries, Government of Tamil Nadu. Income of the selected respondents was categorised based on the nature and source of income into: fishing, fishing-related activities and non-fishing activities (including agriculture activities and small business). The assets were categorised into basic assets such as the value of land, house, fridge, television (TV), furniture, motorcycle, livestock, crafts and gears. The debt was classified based on the source such as institutional and non-institutional. Estimated income, asset and debt were represented in tabular form and their inequality was measured by Gini coefficient Index (GI) whcih is the most popular method to assess the 
inequality in many fields (Maio, 2007) including fisheries. GI was calculated using the formula of Arora et al. (1990).

Let the income be in the order, E1<E2 $<\mathrm{E} 3<\mathrm{E} 3 \ldots \ldots<\mathrm{En}$

Then the Gini Coefficient (GI) is given by:

$$
G I=\frac{1}{(n-1)} \sum_{i=n}^{n} \text { ei }[2 i-(n+1)]
$$

where, $E^{\prime}=$ mean income of groups $E n ; I=1,2,3, n$ respondents and $\mathrm{n}$ is the number of individuals (respondents)

Higher the value of GI, the greater is the degree of inequality between upper and lower income groups of fishermen households which means the coefficient value of 0 represents the equal distribution of income and coefficient 1 represents unequal distribution of income among the society.

The regression approach was adopted to know the significant variables influencing asset, debt and income.

$$
\mathrm{Y}=\mathrm{a}+\mathrm{bX}
$$

where, $\quad \mathrm{Y}=$ dependent variable, $\mathrm{a}=$ intercept and $\mathrm{x}=$ independent variable. The entire analysis was done using Statistical Package for the Social Science (SPSS), version 20.

\section{Results and discussion}

Income of the cooperative society respondents is presented in Table 1. Non-fishing activities were seen to generate greater income than that of the fishing and fishing allied activities. The highest income in fishing (₹3275) and fishing allied activities (₹1200) was earned by Andipatti Society and in non-fishing (₹6272) by Vaigai Society. A congruent picture was observed in Theni by Marimuthu et al. (2015) with an average income of ₹2800 earned in fishing, ₹617 in fishing allied works and ₹5096 in non-fishing activities. A similar study in western Tripura stated that 77,12 and $7.5 \%$ of fishers' generated income more than ₹3000, 2000 - 3000 and 1000 - 2000, respectively from aquaculture only (Pandey and Upadhayay, 2012). The economics of fish farmers of Jammu studied by
Kumar et al. (2015) revealed that, nearly about $66 \%$ of fishers had lower income (₹3000) and that 36\% of fishers' fall under medium level income group. However, a disputed statement was reported by Kumari and Patra (2014) that, about $34 \%$ of inland fishers had income range of 5000 to 10000 per month, $48 \%$ of fishers' income ranged from 10000 to 15000 per month, $15 \%$ of fishers earned 15000 to 20000 per month and the remaining 3\% had income of 20000 to 25000 per month in Angul District of Odisha. Moreover, the fishing income was reported to be directly proportional to fish caught (Kundu, 2011). For better livelihood, state fisheries department stocked 14.04 lakhs fingerlings in Vaigai, 0.74 lakhs in Manjalar and 0.22 lakhs in Shanmuganathi during 2011-12 and in turn harvested $24.67 ; 13.26$ and $1.49 \mathrm{t}$ of fishes from the water bodies respectively. The inland fish production in 2011-12 was estimated at 3422.26 t with an annual growth rate of $1.85 \%$. The stocked (catla, roghu, mrigal) and un-stocked (tilapia) species also contributed (TNSFD, 2014). The average fish catch of $44.57,47.83$ and $7.60 \%$ of fishers were 3-5, 6-8 and 9-10 $\mathrm{kg}^{-1 a{ }^{-1}}$ respectively in Beki River and maximum landing was recorded in gillnet (33\%), followed by cast net $(27 \%)$, scoop net $(24 \%)$, line (10\%) and traps (6\%) (Kalita et al., 2015).

Income from fishing allied works was found to be lower and this may be due to seasonal nature of the work. Hence, the minimum income of ₹225 was recorded in Theni and highest of ₹1200 in Andipatti cooperative fishers' society. In non-fishing activities, higher income generated has been ascribed to natural endowment including Vaigai dam. The dam irrigates more than 2.25 lakh ha areas of agricultural land in Tamil Nadu with canal length of $32.30 \mathrm{~km}$ (DSHB, 2014).

Gini coefficient indicates the deviation of income from the mean. It is the area between the perfect equality and the line of perfect inequality. The income GI result is presented in Fig. 1. In fishing activities, GI was found to be lower for Theni $(0.081)$ and Cumbum compared to Periyakulam (0.085), Kullapuram (0.096), Vaigai (0.106), Andipatti (0.108) and Bodi (0.129) cooperative societies. A higher inequality was recorded in fishing allied works even though it generated lower income. In fishing allied

Table 1. Mean income of the respondents (₹ per month)

\begin{tabular}{llll}
\hline Name of the cooperative society & Fishing activities $(₹)$ & Fishing allied activities (₹) & Non-fishing activities (₹) \\
\hline Andipatti & 3275.00 & 1200.00 & 3975.00 \\
Bodi & 2950.00 & 700.00 & 4075.00 \\
Cumbum & 2650.00 & 650.00 & 5150.00 \\
Kullapuram & 2575.00 & 450.00 & 5275.00 \\
Periyakulam & 3066.67 & 555.56 & 5527.78 \\
Theni & 2575.00 & 225.00 & 5325.00 \\
Vaigai & 2659.09 & 545.45 & 6272.73 \\
\hline
\end{tabular}




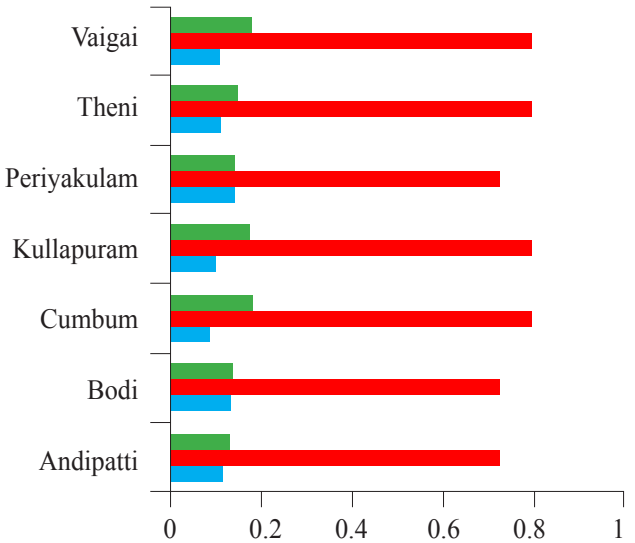

Non-fishing activities, $\square$ Fishing related activities, $\square$ Fishing activities

Fig. 1. Income Gini coefficient index for the selected cooperative societies in Theni District

works, fishers of the cooperative societies viz., Andipatti, Bodi and Periyakulam had homogenous income with GI of 0.73 while fishers of Cumbum, Kullapuram and Vaigai had GI of 0.80. In non-fishing activities too, Andipatti society fishers had a lower GI of 0.126 and a high GI of 0.179 was recorded for Cumbum. However, high homogenous income was observed in fishing activities than in non-fishing activities and fisheries allied works. Fishing GI was found to be lower in the present study than that reported by Mohd et al. (1993) and Wamukota et al. (2014). Mohd et al. (1993) calculated the GI for fishing income and total income (includes non-fishing activities) as 0.3387 and 0.3456 respectively in Malacca, Malaysia. Wamukota et al. (2014) found higher income equalities in sea cucumber fishery with a GI of 0.37 than octopus fishery with a GI of 0.63. Aghazadeh (1994) reported that income was uneven within the fish farmers' community and a huge difference was perceived.

Table 2 shows the asset value (movable and immovable) of inland cooperative society fishers. The highest average level of assets was observed in Vagai followed by Kullapuram, Theni, Bodi, Periyakulam, Cumbum and Andipatti. However, no livestock was recorded in Kullapuram. Basavakumar et al. (2012) studied the assets of fishers household including home, fishing gears and craft, lands, livestock and others. Around $56 \%$ of fishermen families had assets value of less than ₹ $30,000,13 \%$ had assets of ₹30,001 to $45,000,9 \%$ had $₹ 45,001$ to 60,000 and $12 \%$ of fishers had an asset value of more than ₹60,000. However, as compared to the above study (Basavakumar et al., 2012), in the present study area, fishers had higher value of asset. Kupo (2009) documented that, when the asset holding of the respondent was high (above ₹ 2,50,000), land contributed around $73 \%$ of the total assets. Table 2 clearly shows that fishers holding higher land asset value had a lower asset value of livestock and house. Kupo (2009) also supported this. But, the total asset value of inland fishers of Theni Ddistrict was less than the average household value of ₹ 306967 in India as reported by Subramanian and Jayaraj (2006).

The asset inequality is depicted in Fig. 2 which reveals that fridge and livestock inequality was higher for all cooperative societies except Kullapuram. Homogenous equality was noticed among fishing crafts and gears which proved that the economic value of the crafts and gears was more or less similar as confirmed by the GI range of 0.06

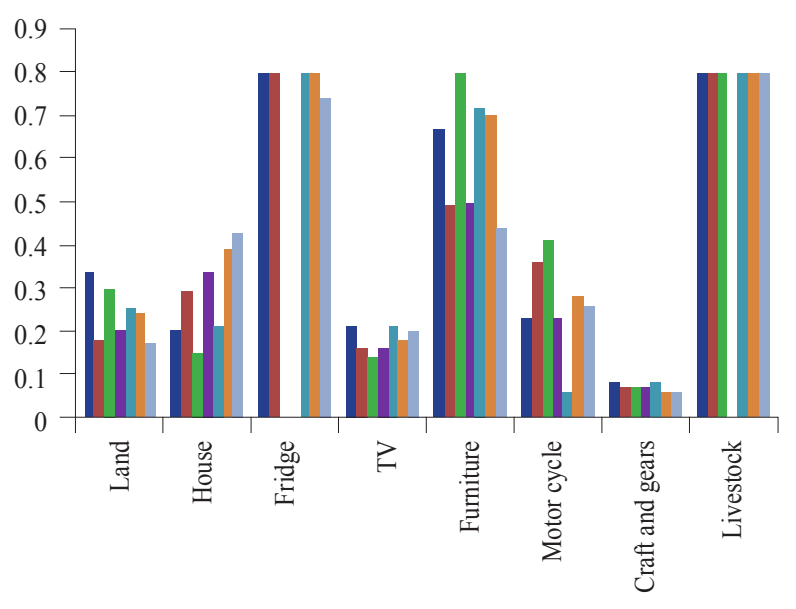

Andipatti, B Bodi, Cumbum, Kullapuram, = Periyakulam,

Theni, - Vaigai

Fig. 2. Asset Gini coefficient

Table 2. Assets of the inland cooperative society fishermen

\begin{tabular}{|c|c|c|c|c|c|c|c|c|}
\hline $\begin{array}{l}\text { Name of the cooperative } \\
\text { society }\end{array}$ & Land (₹) & House (₹) & Fridge (₹) & TV (₹) & Furniture (₹) & Motorcycle (₹) & Craft and gear (₹) & Livestock (₹) \\
\hline Andipatti & 50000 & 33750 & 2000 & 2600 & 2400 & 7000 & 64950 & 5500 \\
\hline Bodi & 71000 & 57500 & 3500 & 3475 & 5150 & 25000 & 63500 & 3750 \\
\hline Cumbum & 55500 & 30750 & 0 & 2600 & 325 & 35000 & 63250 & 5750 \\
\hline Kullapuram & 64500 & 109000 & 0 & 3300 & 2950 & 27000 & 61750 & 0 \\
\hline Periyakulam & 64000 & 57000 & 2500 & 3550 & 5882 & 3525 & 65000 & 2000 \\
\hline Theni & 65500 & 58250 & 4750 & 3150 & 3350 & 52000 & 63850 & 4000 \\
\hline Vaigai & 73000 & 175000 & 7000 & 3475 & 4500 & 18750 & 64350 & 8500 \\
\hline
\end{tabular}


to 0.08 . A coefficient of 0.15 to 0.43 reflects the partial equality of households. A coefficient of 0 represents the perfectly equal distribution of fridge for Cumbum and Kullapuram and livestock for Kullapuram. Belton et al. (2015) reported that with increasing aquaculture practices, the land inequality of leased land decreased as compared to own land.

Debt of inland cooperative society fisherman is presented in Table 3 which shows that highest debt of ₹43600 of institutional and ₹3750 of non-institutional was recorded in Vaigai Society. The lowest debt (₹12250) was noticed in Cumbum Society fishers. Institutional debt was found to be highest compared to the non-institutional counterpart and this could be attributed to the lower

Table 3. Debt of inland cooperative society fishermen

\begin{tabular}{lll}
$\begin{array}{l}\text { Name of the } \\
\text { cooperative society }\end{array}$ & $\begin{array}{l}\text { Institutional } \\
\text { debt (₹) }\end{array}$ & $\begin{array}{l}\text { Non-institutional } \\
\text { debt (₹) }\end{array}$ \\
\hline Andipatti & 16250 & 7450 \\
Bodi & 14500 & 5200 \\
Cumbum & 12250 & 4600 \\
Kullapuram & 24225 & 1500 \\
periyakulam & 35750 & 5350 \\
Theni & 30150 & 6950 \\
Vaigai & 43600 & 3750 \\
\hline
\end{tabular}

interest rate of 10 to $14 \%$. Non-institutional finance has been charged 3 to 5 times higher interest rate than institutional; exerting a heavy burden on fishers and it affects the economic status too. Cumbum Society fishers had better performance in terms of less debt as compared to other cooperative societies (Table 3). Srivastava et al. (1986) stated that mechanised fishing crafts have lower income indebtedness due to sustained potential income. Fishers' were ready to link with cooperative society, as financial source as well as for marketing, besides small amounts of loans aslo sourced from the institutions.

A higher debt inequality was observed in both institutional and non-institutional debts. At the institutional level, a minimum GI of 0.59 was observed in Vaigai and maximum of 0.76 in Kullapuram. But in non-institutional debt, minimum GI was found in Andipatti (0.60) and maximum at Theni (0.73). Nevertheless, Fig. 3 indicates that only a few were having debt. The same was evidenced from unequal debt distribution within the society.

\section{Regression approach}

The beta coefficient value of the multiple regression approach for asset and debt is given in Table 4 and 5 . Debt was negatively influenced by the asset of Andipatti (0.002), Cumbum (0.180) and Vaigai (-0.180) cooperative society fishers which was statistically significant $(\mathrm{p}<0.05)$ for Vaigai.

A multiple regression was run to predict the income of fishing, fishing-related and non-fishing activities from the debt sources (commercial banks, private banks, moneylenders, merchants, cooperative societies, friends and relatives) and asset (land, house, fridge, television, furniture, motorcycle, craft and gears, livestock) (Table 6a,b). In fishing activities, private bank and television were statistically significant $(\mathrm{p}<0.05$, $\mathrm{R}^{2}=0.869$ ) with a beta coefficient of -0.133 and -0.501 respectively for the Andipatti cooperative society. This implied that for each increase of $1 \%$ private bank loan, there was a decrease in gross revenue of -0.133 from

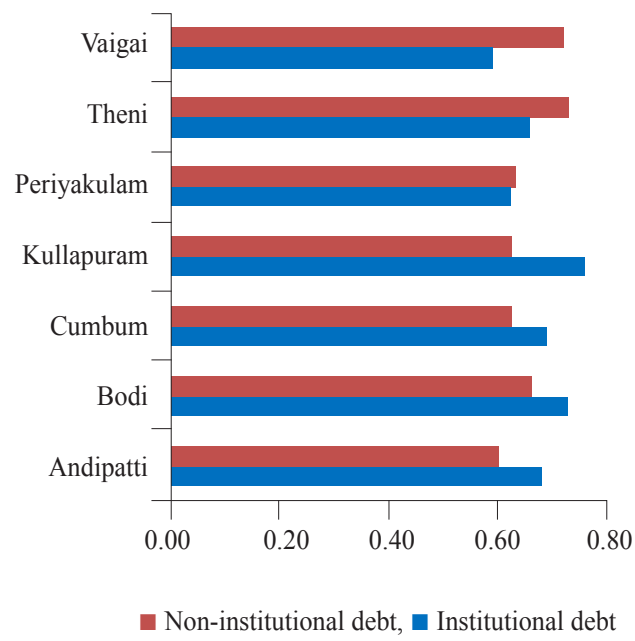

Fig. 3. Debt Gini coefficient

Table 4. Regression coefficient for asset

\begin{tabular}{llllllll}
$\begin{array}{l}\text { Name of the } \\
\text { cooperative society }\end{array}$ & Andipatti & Bodi & Cumbum & Kullapuram & Periyakulam & Theni & Vaigai \\
\hline Constant & $147443.7^{*}$ & 120554.9 & 139815.4 & 128550.8 & 100997.8 & $245096.9^{*}$ & 26349.74 \\
Fishing & -5.367 & -13.851 & 4.907 & -3.841 & 5.516 & 8.772 & 93.603 \\
Fishing allied & 4.526 & -8.938 & 5.930 & 44.999 & 1.603 & -0.578 & 27.519 \\
Non-fishing & -6.066 & 23.533 & -4.960 & 15.088 & 5.798 & -14.310 & 11.535 \\
Debt & -0.005 & 0.168 & 0.305 & 0.167 & -0.184 & 0.284 & $-1.456^{*}$ \\
R & 0.292 & 0.533 & 0.277 & 0.491 & 0.263 & 0.413 & 0.682 \\
R Square & 0.086 & 0.284 & 0.077 & 0.241 & 0.069 & 0.171 & 0.464 \\
\hline
\end{tabular}

"Statistically significant at 0.005 level 
Table 5. Regression coefficient for debt

\begin{tabular}{|c|c|c|c|c|c|c|c|c|c|c|c|c|}
\hline \multicolumn{3}{|l|}{$\begin{array}{l}\text { Name of the } \\
\text { cooperative society }\end{array}$} & Bodi & \multicolumn{2}{|l|}{ Cumbum } & Kullapuram & \multicolumn{2}{|c|}{ Periyakulam } & \multicolumn{2}{|c|}{ Theni } & \multicolumn{2}{|l|}{ Vaigai } \\
\hline Constant & \multicolumn{2}{|c|}{11920.6} & 39674.6 & \multicolumn{2}{|l|}{1853.2} & -23445.0 & \multicolumn{2}{|c|}{89984.7} & \multicolumn{2}{|c|}{-93611.4} & \multicolumn{2}{|c|}{140675.3} \\
\hline Fishing & \multicolumn{2}{|c|}{1.862} & -4.893 & 0.880 & \multicolumn{2}{|c|}{23.165} & \multicolumn{2}{|c|}{1.821} & \multicolumn{2}{|c|}{11.109} & \multicolumn{2}{|c|}{-16.915} \\
\hline Fishing allied & \multicolumn{2}{|c|}{-2.788} & -3.803 & 1.559 & \multicolumn{2}{|c|}{-6.388} & \multicolumn{2}{|c|}{-2.764} & \multicolumn{2}{|c|}{-5.860} & \multicolumn{2}{|c|}{0.017} \\
\hline Non-fishing & \multicolumn{2}{|c|}{2.099} & -2.210 & 0.943 & \multicolumn{2}{|c|}{-3.920} & \multicolumn{2}{|c|}{-4.707} & 12.66 & & 0.761 & \\
\hline Asset & -0.0 & & 0.035 & 0.053 & & & -0.1 & & 0.165 & & $-0.180^{\circ}$ & \\
\hline $\mathrm{R}$ & 0.22 & & 0.267 & 0.199 & & & 0.25 & & 0.481 & & 0.635 & \\
\hline R Square & 0.05 & & 0.071 & 0.040 & & & 0.0 & & 0.232 & & 0.403 & \\
\hline & & Andipatti & & & Bodi & & & umbum & & & ullapuram & \\
\hline cooperative society & Fishing & $\begin{array}{l}\text { Fishing } \\
\text { related }\end{array}$ & $\begin{array}{l}\text { Non- } \\
\text { fishing }\end{array}$ & Fishing & $\begin{array}{l}\text { Fishing } \\
\text { related }\end{array}$ & $\begin{array}{l}\text { Non- } \\
\text { fishing }\end{array}$ & Fishing & $\begin{array}{l}\text { Fishing } \\
\text { related }\end{array}$ & $\begin{array}{l}\text { Non- } \\
\text { fishing }\end{array}$ & Fishing & $\begin{array}{l}\text { Fishing } \\
\text { related }\end{array}$ & $\begin{array}{l}\text { Non- } \\
\text { fishing }\end{array}$ \\
\hline Constant & $6261.57^{*}$ & 2499.37 & 9209.43 & 3021.22 & 5817.48 & 1545.72 & $3536.81^{*}$ & -2661.02 & 4181.42 & 1901.44 & -3258.43 & -59.24 \\
\hline Commercial banks & 0.009 & -0.013 & 0.004 & -0.016 & -0.037 & 0.003 & -0.02 & 0.07 & -0.005 & -0.002 & -0.01 & -0.007 \\
\hline Private banks & $-0.133^{*}$ & -0.083 & 0.028 & 0.006 & -0.038 & -0.012 & -0.002 & 0.025 & -0.025 & 0.05 & -0.06 & -0.041 \\
\hline Moneylenders & -0.002 & 0.08 & 0.027 & 0.049 & -0.163 & 0.033 & -0.038 & 0.081 & 0.003 & 0.02 & 0.143 & 0.035 \\
\hline Merchants & -0.14 & -0.133 & 0.057 & 0.082 & 0.011 & 0.642 & -0.043 & 0.255 & -0.606 & 0.259 & 0.188 & 0.218 \\
\hline Cooperatives societies & -0.016 & -0.122 & -0.037 & -0.06 & -0.588 & 0.293 & -0.086 & $0.633^{*}$ & 0.009 & -0.022 & -0.033 & 0.056 \\
\hline Friends and relatives & -0.007 & -0.109 & -0.107 & 0.083 & -0.203 & 0.336 & -0.034 & 0.025 & -0.057 & -0.167 & -0.137 & 0.267 \\
\hline Land & 0.009 & 0.037 & 0.002 & -0.011 & -0.013 & -0.024 & $0.009^{*}$ & -0.004 & 0.006 & -0.004 & -0.001 & -0.005 \\
\hline House & -0.004 & 0.015 & 0.01 & -0.007 & 0.012 & 0.003 & 0.026 & -0.002 & -0.003 & -0.003 & -0.006 & 0.003 \\
\hline Fridge & 0.003 & 0.155 & 0.078 & -0.038 & -0.055 & -0.058 & -0.12 & 0.337 & -0.269 & - & - & - \\
\hline TV & $-0.501^{*}$ & -0.204 & -0.252 & 0.342 & 0.181 & 0.79 & -0.012 & 0.027 & -0.758 & 0.71 & 1.479 & 0.836 \\
\hline Furniture & -0.025 & 0.067 & -0.184 & -0.091 & -0.242 & -0.035 & -0.005 & 0.01 & -0.024 & -0.251 & -0.291 & -0.102 \\
\hline Motorcycle & -0.015 & -0.219 & -0.152 & 0.012 & 0.035 & 0.035 & -0.226 & 0.098 & 0.451 & -0.011 & 0.034 & 0.017 \\
\hline Craft and gear & -0.24 & -0.344 & -0.573 & -0.01 & -0.464 & 0.053 & 0.008 & 0.04 & 0 & 0.006 & -0.04 & 0.282 \\
\hline Livestock & 0.022 & 0.012 & -0.051 & -0.023 & -0.069 & -0.03 & - & - & - & - & - & - \\
\hline $\mathrm{R}$ & 0.932 & 0.91 & 0.646 & 0.815 & 0.703 & $.903 \mathrm{a}$ & 0.925 & 0.842 & 0.758 & 0.773 & 0.771 & $.700 \mathrm{a}$ \\
\hline R Square & 0.869 & 0.827 & 0.417 & 0.664 & 0.494 & 0.816 & 0.856 & 0.709 & 0.575 & 0.598 & 0.595 & 0.49 \\
\hline Durbin-Watson & 2.417 & 1.684 & 2.125 & 2.809 & 3.005 & 1.886 & 1.891 & 2.925 & 2.389 & 3.018 & 1.399 & 2.198 \\
\hline
\end{tabular}

*Statistically significant at 0.05 level

Table 6b. Regression coefficient value for income from fishing, fishing-related and non-fishing works

\begin{tabular}{|c|c|c|c|c|c|c|c|c|c|}
\hline \multirow{2}{*}{$\begin{array}{l}\text { Name of the } \\
\text { cooperative society }\end{array}$} & \multicolumn{3}{|c|}{ Periyakulam } & \multicolumn{3}{|c|}{ Theni } & \multicolumn{3}{|c|}{ Vaigai } \\
\hline & Fishing & Fishing related & Non-fishing & Fishing & Fishing related & Non-fishing & Fishing & Fishing related & Non-fishing \\
\hline Constant & 5462.03 & $-8858.02^{*}$ & 12414.09 & -988.81 & -3173.74 & 19355.07 & 2372.81 & -9189.21 & 7898.99 \\
\hline Commercial banks & -0.001 & $-0.009^{*}$ & 0.001 & 0.003 & -0.002 & 0.007 & 0.002 & 0.021 & 0.022 \\
\hline Private banks & -0.002 & $-0.026^{*}$ & 0.048 & 0.006 & 0.022 & 0.016 & -0.003 & 0.024 & -0.001 \\
\hline Moneylenders & -0.009 & -0.077 & 0.091 & 0.011 & 0.008 & 0.039 & - & - & - \\
\hline Merchants & -0.081 & -0.05 & 0.03 & 0.136 & 0.244 & -0.076 & -0.007 & 0.065 & -0.151 \\
\hline Cooperative societies & 0.051 & 0.087 & -0.166 & -0.004 & 0.064 & -0.228 & 0.109 & 0.9 & -1.316 \\
\hline Friends and relatives & -0.216 & -0.403 & 0.314 & 0.695 & 1.067 & -0.781 & 0.018 & 0.113 & -0.121 \\
\hline Land & -0.001 & $-0.02^{*}$ & 0.031 & -0.006 & 0.001 & -0.018 & 0.004 & 0.007 & 0.045 \\
\hline House & 0.014 & -0.022 & -0.033 & 0.003 & 0.006 & 0.002 & -0.001 & -0.012 & 0.014 \\
\hline Fridge & 0.016 & -0.101 & 0.049 & -0.002 & -0.107 & -0.025 & 0.034 & -0.023 & -0.071 \\
\hline $\mathrm{TV}$ & -0.132 & -0.233 & 0.121 & 0.389 & 0.548 & -1.004 & -0.197 & 0.72 & -0.275 \\
\hline Furniture & -0.036 & $0.124^{*}$ & 0.007 & 0.125 & 0.344 & -0.344 & 0.06 & 0.312 & -0.093 \\
\hline Motorcycle & -0.09 & $2.302^{*}$ & -1.009 & 0.033 & 0.044 & -0.081 & -0.021 & -0.05 & 0.026 \\
\hline Craft and gear & -0.31 & $0.837^{*}$ & -0.691 & 0.012 & -0.323 & -0.683 & 0.093 & 1.032 & -0.724 \\
\hline Livestock & 0.022 & 0.012 & -0.093 & -0.01 & -0.021 & 0.044 & 0.009 & 0.01 & -0.02 \\
\hline $\mathrm{R}$ & 0.88 & 0.984 & 0.832 & 0.829 & 0.903 & $.875 \mathrm{a}$ & 0.858 & 0.86 & 0.867 \\
\hline R Square & 0.774 & 0.969 & 0.693 & 0.687 & 0.815 & 0.766 & 0.737 & 0.739 & 0.751 \\
\hline Durbin-Watson & 2.146 & 2.452 & 2.63 & 2.261 & 2.064 & 2.206 & 2.42 & 2.568 & 2.29 \\
\hline
\end{tabular}

${ }^{*}$ Statistically significannt at 0.05 level 
fishing activities. Similarly, land (0.633) was statistically significant $\left(\mathrm{p}<0.05, \mathrm{R}^{2}=0.856\right)$ for fishing activities and the cooperative societies (0.009) were statistically significant $\left(\mathrm{p}<0.05, \mathrm{R}^{2}=0.709\right)$ for fishing related activities in Cumbum cooperative society. This showed that, for every $1 \%$ increase of loan, the income increased by 0.009 in fishing related activities. In Periyakulam, commercial banks, private banks and land, negatively influenced the mean income of fishing related activities with a beta coefficient of $-0.009,-0.026,-0.02$ respectively, while furniture, motorcycle, fishing craft and gears positively influenced the same by a beta coefficient of $0.124,2.302$, $0.837\left(\mathrm{p}<0.05, \mathrm{R}^{2}=0.969\right)$. The Durbin-Watson measures the autocorrelation and signified negative correlation between the adjacent residual income from fishing, fishing-related and non-fishing activities for Periyakulam, Theni and Vaigai cooperative societies. Other societies had positive and negative autocorrelations. Field (2009) represented that if the value was less than 1 or more than 3 , it undoubtedly attracts concern. But, in the present study, this doesn't have any say since time series data was not used. The debt had a negative attitude towards the income of fishing allied works for Andipatti and Bodi cooperative societies. It was also found that assets had a negative association with income of non-fishing activities in all the cooperative society fishers except Bodi and Kullapuram.

Income inequality has enlarged noticeably over the epochs. Nevertheless, top earners bagged the higher share of the total income gain, others witnessing only an inconsequential rise in income. Therefore, valuation of an economic performance should not only focus on overall income growth, but also ought to account the income distribution (OECD, 2012). In the present study it was found that, highest income was earned from the non-fishing with lower income inequality than that of the fishing and fishing allied activities. A larger income inequality was noticed in fishing allied works due to irregularity of jobs. A lowest asset inequality was logged in fishing gear and craft, television, and land and highest in furniture and livestock. Besides, the debt was primarily sourced from institutional rather than non-institutional sources, owing to higher interest rate. However, results of the study indicate that fishers had lower income inequality except in fishing related works; no remarkable variation in assets inequality and a greater debt inequality in the study area,

\section{Acknowledgements}

The authors would like to thank Ms. Amali Infantina, who provided assistance to accomplish this work with maximum possible clarity. Authors are also thankful to the anonymous reviewers for critical comments and suggestions. The Tamil Nadu Fisheries University supported this study. We are also grateful to Inland Fishers of Theni District who provided the information to carry out this study successfully.

\section{References}

Aghazadeh, E. 1994. Fisheries: socio-economic analysis and policy. Technical report assistance, Submitted to the Fisheries Research Institute, Bangladesh. Food and Agricultural Organisation of the United Nations, Bangladesh.

Ahluwalia, M. S. 1974. Income inequality: some dimensions of the problem. Financ. Dev., 11(3): 2.

Arora, S., Julka, A. A. and Bagai, O. P. 1990. Testing the significance related to gini ratio, non-parametric test statistics. J. Indian Soc. Agric. Stat. 118-130.

Baran, E., Jantunen, T. and Chong, C. K. 2007. Values of inland fisheries in the Mekong River Basin. World Fish Center, Phnom Penh, Cambodia, p. 1-76.

Basavakumar, K. V., Devendrappa, S. and Srenivas, S. T. 2012. A study on profile of fishing community of a village in Karnataka. Karnataka J. Agric. Sci., 24(5): (684-687).

Belton, B., Ahmed, N. and Murshed-e-Jahan, K. 2015. Aquaculture, employment, poverty, food security and well-being in Bangladesh: A comparative study. World Fish. Cambodia, p. 1-72.

Birdsall, N. and Londono, J. L. 1997. Asset inequality matters: an assessment of the World Bank's approach to poverty reduction. American. Econ. Rev., 87(2): 32-37.

Cingano, F. 2014. Trends in income inequality and its impact on economic growth, OECD Social, Employment and Migration Working Papers. OECD Publishing no. 163, p. 6-30.

DSHB 2014. District Stastistical Hand Book database. http:// www.theni.tn.nic.in/pdfs/statistics.pdf

Field, A. 2009. Discovering statistics using SPSS, SAGE Publications, New Delhi, p. 311-328.

Forbes, K. J. 2000. A reassessment of the relationship between inequality and growth. American. Econ. Rev., 90: 867-889.

Fredriksen, K. B. 2012. Less income inequality and more growth - are they compatible? Part 6 . The distribution of wealth. http://dx.doi.org/10.1787/5jxrjncwxv6j-en

Iacoviello, M. 2008. Household debt and income inequality, 1963-2003. J. Mon. Cre. Ban., 40(5): 929-965.

Kalita, G. J., Sarma, P. K., Goswami, P. and Rout, S. 2015. Socio-economic status of fishermen and different fishing gear used in Beki River, Barpeta, Assam. J. Ent. Zool. Stud., 3(1): 193-198.

Krueger, D. and Perri, F. 2006. Does income inequality lead to consumption inequality? Evidence and theory. Rev. Econ. Stud., 73(1): 163-193. 
Kumar, P., Khar, S., Sharma, R., Choudhary, P., Himabindu, K. V., Sharma, S., Sharma, S. K. and Jagmohan, S. 2015. Identifying socio-economic features of fish farmers. Agro. Econ., 2(1): 27-31.

Kumari, M. K. and Patra, S. 2014. Production analysis of inland fish in Angul District of Odisha. J. Econ. Financ., 3: 38-42.

Kundu, S. K. 2011. Inland is fishing activities in Kumarganj Block of Dakshin Dinajpur District. J. Inter., 15: 648-656.

Lynch, A. J., Cooke, S. J., Deines, A. M., Bower, S. D., Bunnell, D. B., Cowx, I. G., Nguyen, V. M., Nohner, J., Phouthavong, K., Riley, B. and Rogers, M. W. 2016. The social, economic and environmental importance of inland fish and fisheries. Environ Rev., 24(2): 115-121.

Marimuthu, R., Rajakumar, M., Senthilateban, R. and Radhakrishnan, K. 2015. Study on income and expenditure of inland fishermen in Theni Province, India. Econ. Affairs, 60(4): 747-751.

Maio, F. G. De 2007. Income inequality measures. J. Epidemiol. Community Health, 61(10): 849-852.

Mohd, K., Kuperan, K. and Yew, T. S. 1993. Incidence and determinants of non-fishing employment among fishermen: Case study of the State of Malacca, Malaysia. In: Paper presented at the International Association tor the Study of Common Property (1ASCP), Fourth Annual Common Property Conference, 15-19 June, 1993. Philippine Village Hotel, Manila, Philippines. p. 11-29.
Nath, K. 2015. Production and market efficiency for inland fisheries in North-east India: The empirical study of Lohit and Lower Subansiri districts of Arunachal Pradesh. Int. J. Fish. Aquat. Stud., 2(5): 39-45.

OECD 2012. Reducing income inequality while boosting economic growth: Can it be done? Evidence from OECD countries. Economic Policy Reforms 2012: Going for Growth, p. 181-202.

Pandey, D. K. and Upadhayay, A. D. 2012. Socio-economic profile of fish farmers of an adopted model aquaculture village, Kulubari, West Tripura. Indian Res. J. Ext. Educ., 2: 55 .

Srivastava, U. K., Dharmareddy, M., Subrahmanyam, B. and Gupta, V. K. 1986. Impact of mechanization on small fishermen: Analysis and village studies. Concept Publishing Company, New Delhi, p. 99-130.

Subramanian, S. and Jayaraj, D. 2006. The distribution of household wealth in India, UNU-WIDER, United Nations University (UNU), No. 2006/116, ISBN 9291909009

TNSFD 2014. Tamil Nadu State Fisheries Department database. http://www.theni.tn.nic.in/pdfs/fisheries.pdf

Wamukota, A., Brewer, T. D. and Crona, B. 2014. Market integration and its relation to income distribution and inequality among fishers and traders: The case of two small-scale Kenyan reef fisheries. Mar Policy., 48: 0 93-101. 